\title{
The Practices of Communicative English of Customer Service Officers in Adisutjipto International Airport Yogyakarta
}

\author{
Praktek Bahasa Inggris Komunikatif Petugas Layanan Pelanggan di Bandara \\ Internasional Adisutjipto Yogyakarta
}

\author{
Ajeng Kusumaning Ratri ${ }^{1}$, Dewi Cahya Ambarwati ${ }^{*}$ \\ Universitas Gadjah Mada ${ }^{1,2}$ \\ ajengkratri@gmail.com¹, dewica2021@gmail.com²
}

\begin{abstract}
This article described the performance of communicative English for the customer service officers (CSO) in Adisutjipto International Airport. PT. Angkasa Pura I Adisutjipto International Airport (AP 1 JOG) aims to provide an excellent service to the passengers by having communication skill in English. Data were collected using qualitative method by employing interviews, field notes taking and photographs documentation. The result showed that communication is the foremost key for the CSOs to provide an excellent service. It is also significant to have a strong communication skill in English. The function in mastering English for them is not only to communicate, but also to open more opportunities for the company to grow internationally. The result of this study contributed to identify the communicative English skill for the CSOs in Adisutjipto International Airport in recognition of its international status. Speaking skill was considered to be the most important skill compared to other skills, i.e. listening, reading, and writing. Moreover, The result found that there were several listening, reading and writing problems faced by the CSOs. It provided some insights into the assessment of English performance of the CSOs in Adisutjipto International Airport for a better service.
\end{abstract}

Keyword: Adisutjipto International Airport, Customer Service Officer, English, Communication

\section{INTISARI}

Artikel ini menjelaskan kinerja bahasa Inggris komunikatif untuk petugas layanan pelanggan (CSO) di Bandara Internasional Adisutjipto. PT. Angkasa Pura I Bandara Internasional Adisutjipto (AP 1 JOG) memiliki tujuan untuk memberikan pelayanan yang prima kepada para penumpang internasional melalui pelayanan berbahasa Inggris. Pengumpulan data dilakukan dengan metode kualitatif melalui wawancara, pencatatan lapangan dan dokumentasi foto. Hasil penelitian menunjukkan bahwa keterampilan komunikasi yang baik, khususnya komunikasi verbal, menjadi kunci utama bagi CSO untuk memberikan pelayanan yang prima. Penelitian ini juga menemukan bahwa penguasaan bahasa Inggris sebagai alat komunikasi global sangat diperlukan bagi CSO. Fungsi penguasaan bahasa Inggris bagi mereka tidak hanya untuk menjalin komunikasi dengan penumpang internasional, tetapi juga untuk membuka lebih banyak peluang bagi perusahaan untuk berkembang secara internasional. Oleh karena itu, kedua elemen tersebut penting untuk dikuasai oleh CSO. Hasil penelitian ini berkontribusi untuk mengidentifikasi kemampuan bahasa Inggris komunikatif CSO di Bandara Internasional Adisutjipto sebagai pengakuan atas status internasionalnya. Selain itu, hasil penelitian ini juga memberikan wawasan tentang penilaian kinerja bahasa Inggris CSO di Bandara Internasional Adisutjipto untuk pelayanan yang lebih baik.

Kata Kunci: Bandara Internasional Adisutjipto, Customer Service Officer, Bahasa Inggris, Komunikasi

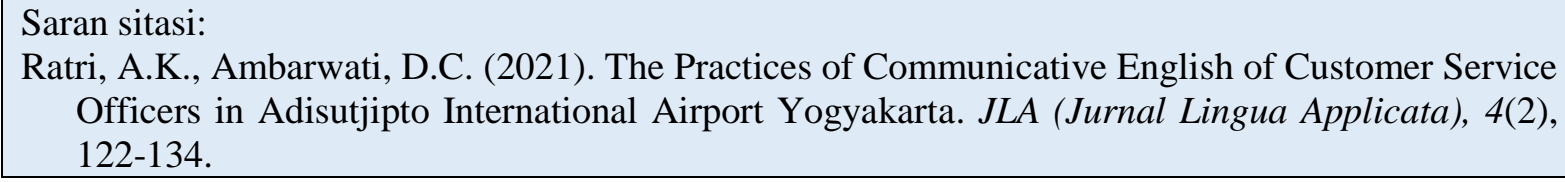
Officers in Adisutjipto International Airport Yogyakarta. JLA (Jurnal Lingua Applicata), 4(2), $122-134$.

\footnotetext{
${ }^{1}$ First author

* Corresponding author
} 


\section{INTRODUCTION}

According to United Nation World Tourism Organization (UNWTO), the arrival number of international tourists has grown by $4.4 \%$ in 2015 . It reached almost 1.2 billion arrivals in total. In comparison to 2014, there were also approximately 50 million tourists went for international destinations around the world. These numbers showed how well international tourism have been growing in the past few years. The growing number of international tourism will also lead to a higher demand of mastering a global communication skill. This issue arises because of there are factors to be fulfilled. Factors - such as; accommodation, transportation, and destination - are the ones that can push a communication to happen.

English has become an important communication tool to overcome the problem of miscommunication in global situation. Barbara Seidlhofer (2005: 339) mentioned that, "the term of 'English as a lingua franca' has emerged as a way of referring to communication in English between speakers with different first language". In fact, the two third of people who use English are non-native speakers. The existence of this language has, indeed, helped people in many cross-cultural situation to communicate their needs or ideas.

When people come to a new country, the first time they legally landed their feet is in the aiport. Most of the public aiport that people use is a part of State-Owned Enterprise (hereafter SOE). However, several airports may also be from the private sector, or the military. Nonetheless, there are also aiport that is managed by the military, but it has to share its function with the public use. Yogyakarta, for instance, has to share the airfield for both public use and military since the airport itself is on the military area, but it is also under a SOE management.

As for Indonesia, according to Directorate General of Civil Aviation, there are 297 airports in total. Among these number, 27 among them are international airports, and the rest are domestic ones. Moreover, some of these airports are also managed under two SOEs of the Indonesian Department of Transport, which are PT. Angkasa Pura I and PT. Angkasa Pura II. These two companies are divided into two specific areas in managing the airports. Airports located in the west region are under the management of of PT. Angkasa Pura II, whilst the middle and east region are on the hand of PT. Angkasa Pura I.

As a company concentrating in transportation, P.T. Angkasa Pura surely wants to make sure that the passengers are comfortable with the service. Thus, the customer service section comes into play. Customer service is front-liner of a company in many business sectors. They are pledged to communicate with the customer (in this case the passengers) and to help them solve their problem regarding the products or service that they find troubling them. A customer service officer (hereafter CSO) is someone that the company trained to communicate very well with the customers to make sure they get the best service. Therefore, a company can maintain not only the quality of their product, but also their service by having a customer service section. 
The general idea to become a CSO is to be good at communication since they directly face the customers. John Hopkins Medicine Guidebook's Service Excellence: Standards of Behaviour, explains how to build a good relationship with customers by having a standard way to communicate. As a CSO, a person should be aware of the way they use verbal communication to speak with the customers. The aim of this study is to examine and determine the role of English as the bridge of communication between the customer service and international passengers. This study will take a closer look on how mastering English has an important role for a global communication.

\section{RESEARCH METHOD}

The study employed qualitative approach for data collection. In order to obtain the data, field study and library study were conducted. In the field study, researcher conducted direct and participant observations, qualitative interviews and notes taking during two-month internship program. This program led to variety of jobs as a CSO in Adisutjipto International Airport, such as helping the passengers, checking the facilities, monitoring the schedules, helping the information desk and having the responsibility to authorize the temporary-pass to Adisutjipto International Airport.

The direct observation allowed researcher to observe the work of CSO outside their main responsibilities. This included the relationship between varieties of sections in Adisutjipto International Airport, the maintenance of airport facilities, the procedures of complain-handling system, and the side-job as a CSO. The sidejob were mostly helping the information desk, picking up the telephone and announcing in the airport. Through direct observation, researcher had the chance to see the framework of varieties of responsibilities in Adisutjipto International Airport. Participant observation was also conducted to see how the CSOs interact with the international passengers. In this case, researcher actively involved and experienced direct interactions with the passengers. Researcher was able to observe more about communication that builds up between the passengers and the CSOs.

Several interviews were conducted to elaborate the data. Researcher conducted interviews with the Customer Service Section Head, as well as with two CSOs. It helped researcher to elaborate on the workloads, responsibilities and experiences of customer services. The qualities the company look for as one of the requirements to become a CSO were asked. The answers were matched with Blanding's, as well as Macaulay and Cook's view on the qualification for a CSO candidate. The interviews also helped to find the standard between the two parties. To complete the data taken from observation and interviews, notes-taking, audio and audiovisual recordings were also conducted. As for the library research, researcher gathered sources from relevant literature, publication, studies, and some supporting references from books and internet resources. However, most of the information about PT. Angkasa Pura I Adisutjipto International Airport (AP $1 \mathrm{JOG})$ are from the official website of Adisutjipto International Airport. After collecting the data, the information was 
separated into different sections and arranged it into paragraphs. Nawamin Prachanant's findings on his article, Need Analysis on English Language Use in Tourism Industry, were used in determining the indicators of communicative English. Furthermore, Prachanant's views were elaborated as well to analyze the result of field observation.

\section{RESULT AND DISCUSSION \\ Customer Service in General}

It is common for a wide-ranged and well-established company to have a customer service section. According to Shankman (2010), customer service people is vital for a social media-based company, as "the first line of attack and defence when it comes to customer communication" (p.13). Meanwhile, Yoeti (1995: 8) stated that customer service could be the key for the hotel to make an improvement in their hospitality. This is because customer service work can evaluate the experiences to set a standard for future references or the current situation. Therefore, the two areas of businesses show the importance of customer service role in their company.

The definition of customer service varies from one to other scholars. Shankman expressed that a company needs "customer service people" to help them communicate better with the customers (2010: 13). Brink and Berndt stated that the customer service "was seen as the exclusive domain of the salesperson who is in direct contact with the customer" (2004: 46). This is the basic idea of why customer service is usually perceived as a department to handle customer complaints. Meanwhile, Yoeti (1995: 8) separated two functions of customer service: as a marketing tool to win more customers and as an evaluation tool to give better service. Essentially, the definition of customer service from each scholars share the same perspective where it sees customers as their priority.

Today, several company has been working to improve their customer service by being a customer-focused organization. Leland and Bailey (2011) stated that a customer-focused company is a company where they focus on profits, but at the same time, they are also working on how to give the best service to the customers (p.21). Macaulay and Cook (1993: 7) gave a further insight that "the truly customer-centered organization has taken the trouble to think through what sort of procedures and structures work best for the customer". Both statements put customers as a center of their company. Figure 1 and 2 show the view on how customer-focused company works.

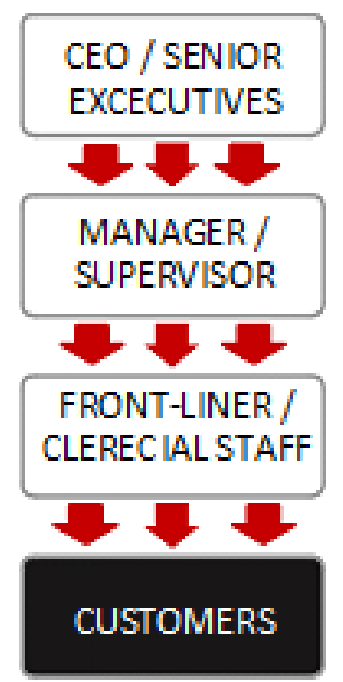

Figure 1. The customer-focused/customer-centered organization

Source: Leland K. and Bailey K. (2011)

Figure 1 shows how the customerfocused company works. The upper 
authority of the company (CEO/Senior Executives) has the responsibility to lead the company accordingly to its vision, brand definition and sustaining the customerfocused culture. The middle authority (Manager/Supervisor) is responsible to promote the excellent standard by providing the proper human resources. Meanwhile the front-liner will be the face of the company by providing an excellent service based the standard of the company to the customers.

Figure 2 describes how customers are the center of the company. It is the core in the company's existence. The company sees customers as the main supply of the firm's life. It believes that in providing the best procedure and services to the customer as its main priority to attract the market. Thus when the markets (customers) are getting larger, the company will also grow bigger.

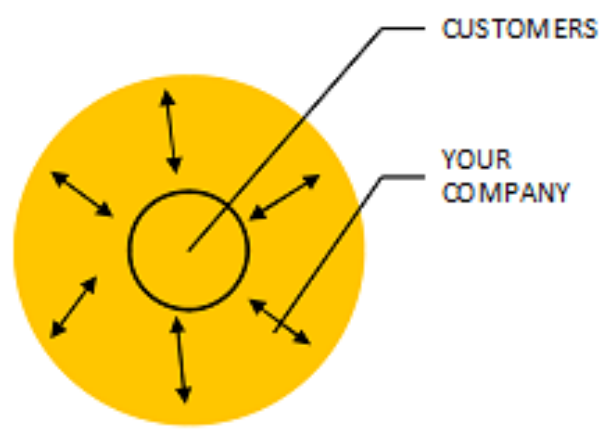

Figure 2. The customer-focused/customer-centered organization

Source: Macaulay \& Cook (1993)

Fundamentally, several companies familiar with the term 'excellent service' on providing the best customer care. The idea of this term is about providing the best service for the customers based on the standard that the company can facilitate (Sutopo \& Suryanto, 2001: 10). They further explained that the indicator of a company successfully gave an excellent service is when there are no complaint from the customers (p.28). Though the standard from one company to another is different, Leland and Bailey (2011: 23) broke down the three basic elements of service excellence:

a. Develop a customer-friendly attitude

This relates to how the employees build a good communication with coworkers or customers, and establish a relationship among them. This element also focuses on making a positive 'moment of truth' or first-impression to the customers.

b. Expanding your definition of service

This element talks about how there is more than just giving the customers what they want. It is when the company gives more attention to the time when they cannot provide the needs of the customers. For instance, listening to them and giving alternative choices.

c. Reconsidering who your customers are

The definition of customer in this element is beyond "the person who buys", but also "the person we are dealing with". Firstly, the "external customer" is the person who buys from outside the company. The second is the "internal customer" who works inside the company, as they also need the company's service, information, or even product.

Sutopo and Suryanto (2001:37) agreed on the idea of the last element where the company should reconsider who their customers are. They argued that if a company can identify who their customers are, then they could recognize the kind of 
service their customers needed in order to minimalize any complaints from them. In order to give an excellent service, a company should set qualifications for a customer service representative (hereafter CSR), or a customer service officer (CSO) in AP 1 JOG. The words 'representative', according to Oxford Dictionary, means "a person who has been chosen to speak or vote on behalf of a group". Therefore, in order to choose a fit candidate for a company's customer service section, the organization must know what they are looking for. Macaulay and Cook agreed that a company should pay attention to several criteria when hiring "customer-contact people" (1993:91). The criteria that they should pay attention to are the clarity of communication, the ability to work under pressure, having a friendly-approachable manner, and having a good organization and priority management. Meanwhile, Blanding (1991:284) stated that for a customer service position, the company should pay attention to the ability of a person in their interpersonal skills, resilience, problemsolving ability, ability to work under pressure, attention to detail, and excellent language skills. Thus, we can see that Macaulay, Cook, and Blanding shared the same idea of having the ability to work under pressure, and the ability to communicate for a customer service position in a company.

\section{English as a Global Communication}

Tool

English has emerged as a global language to communicate around the world. Crystal (1997:3) stated, “a language achieves a genuinely global status when it develops a special role that is recognized in every country". He further explained that in order to gain such 'special role', there are two main ways (1997: 4):

a. Every country has to acknowledge that language as a medium of communication in several areas, such as government, the law courts, the media, and the educational system.

b. A language becomes one of the priority in a country when, even though it is not the official language, the schools teach this language to the children in their foreign-language class.

Furthermore, it has to be the one, which is most available to adults who learned or never learned it during their early educational years. English has reached the stage where over seventy countries around the world has placed it to have a 'special role' in their societies compare to several countries, which also develop a considerable official use (Crystal, 1997: 4). In fact, two third of its users are non-native speakers. Therefore, I can say that English has started to become a global communication tool.

As English has widely known as a global language, many scholars use several terms to address this phenomenon. The term 'English as a lingua franca' (ELF) has become a common term to refer the communication between the non-native speakers. Firth (in Seidlhofer, 2005: 339) stated that:

...what is distinctive about ELF is that, in most cases, it is a 'contact language' between persons who share neither a common native tongue nor a common (national) 
culture, and for whom English is the chosen foreign language of communication.

Another term that scholars commonly use is 'English as an international language' (hereafter EIL) (Seidlhofer, 2005: 339). Sharifian (2009: 2) argued EIL emphasizes that English, as its many varieties, is language of international, and therefore intercultural, communication rather than selecting a particular variety to be the lingua franca. The article suggested that EIL uses International English as a way of communication, rather than deciding on one variety of English, such as British English or American English, to be the lingua franca.

\section{Customer Service and Communication}

Shankman (2010), Leland and Bailey (2011), as well as Macaulay and Cook (1993) shared the same idea how communication is a key to customer service occupation. Additionally, communicating with the customers is far beyond than just giving out the information, it is both verbal and non-verbal communication. Verbal communication is important, however, people often forget how non-verbal communication can be the trigger of why they cannot have a good communication with their customers. The data on how people receive messages from others showed that $55 \%$ comes from the informant's body language, 33\% comes from the tone of voice, and $7 \%$ is from the actual words (Leland \& Bailey, 2011: 151). This means that non-verbal communication, such as body language, is as much as significant with verbal communication.
Researcher found various cases when people want to consult or complaint about a company's product or services, and the first person they meet is a customer service representative. This is why a CSO should be able to read the body language of the customers in order for them to give the right signal that they are there to help (Leland \& Bailey, 2011: 151). As 'the first line attack and defence', a CSO should also be aware of how they transmit the information to the customers since it will affect the 'moment of truth' of the service. Macaulay and Cook proposed the idea that before providing the answers, a CSO must consider several elements, such as "what you intend to say, who will receive it, why you are communicating, how you should choose to get the point over, and when you need to do it" (1993: 67). Therefore, a CSO has to be mindful of when they communicate to the customers as they are in the first line of a company.

An effective communication can be helpful for CSOs in doing their work. According to Macaulay and Cook (1993: 77), effective communication involves attentive listening, good use of question to be more specific to understand the customers situation, awareness of the effect of non-verbal communication such as body language, having a good use of voice (warm, positive and clear) and providing clear explanation. However, Newby and McManus (1991) put the four qualities under the listening skill, and added two more qualities, such as building relationship with the customers by giving them space to steam off, and diagnostic listening by trying to solve the problem after gathering all the facts (pp.31-35). It can be concluded that the 
first and foremost key to build an effective communication with the customers is listening.

The idea of understanding the customer's point of view is a key to a better communication. Attentive listening provides this important point, which is why it is significant for a CSO to have. Newby and McManus (1991: 34) mentioned that having the ability of attentive listening will help the CSO to build a relationship with the customers. It requires the CSOs to listen to the customers, and understand their point of view on the subject that they are discussing. Macaulay and Cook suggested this act as one of key factors in having a smoothflowing communication with the customers (1993:67). This is because when the CSOs understand the concerned issue of the customers, it builds an invisible trust within the customers' mind-set that the CSOs are there to help. Thus, it is easier for them to process the information, and to get through the whole massage on what the CSOs are trying to communicate.

\section{Communicative English}

An excellent language skill as one of the requirement of a CSO is a quality which is essential for customer-contact occupation. This language skill can either be the mother tongue of the CSO or any foreign-languages. An excellent language skill can facilitate the CSOs to have a better communication with the customers. As stated by Macaulay and Cook (1993), a CSO should be aware to whom they speak, and therefore they can select proper words in the language they use as they have a better skill on it.
Shankman (2010) also mentioned that in order to help the company having a better communication to the customers, a CSO should master English as their communication tool. In today's society, English has penetrated deeply in various sectors from economy to communication (Crystal, 1997: 30). By mastering English, a CSO can facilitate and help the company to be more open to potential international customers. Thus, mastering English is a quality that a CSO should have as it opens more opportunity for the company.

From data analysis, researcher recognized there are several skills in using English as a communication tool for CSOs. Most participants chose speaking skill as considerably important among the other skills. The finding is similar with the study conducted by Prachanant (2012). It explained that the cause of this issue was the employees were working directly with the international tourist, which required guiding, interacting and communicating with them (2012: 123). There were several function of English language use as communication tool with the international customers mentioned as well in Prachanant's study. Giving information, providing services to the customers, and offering help were crucial since they require specific language use is tourism industry (Prachanant, 2012: 123).

\section{Applied English for Communication}

Based on the findings as well as previous studies, it can be inferred that English and communication are useful to provide service to international customers (see Figure 3). 


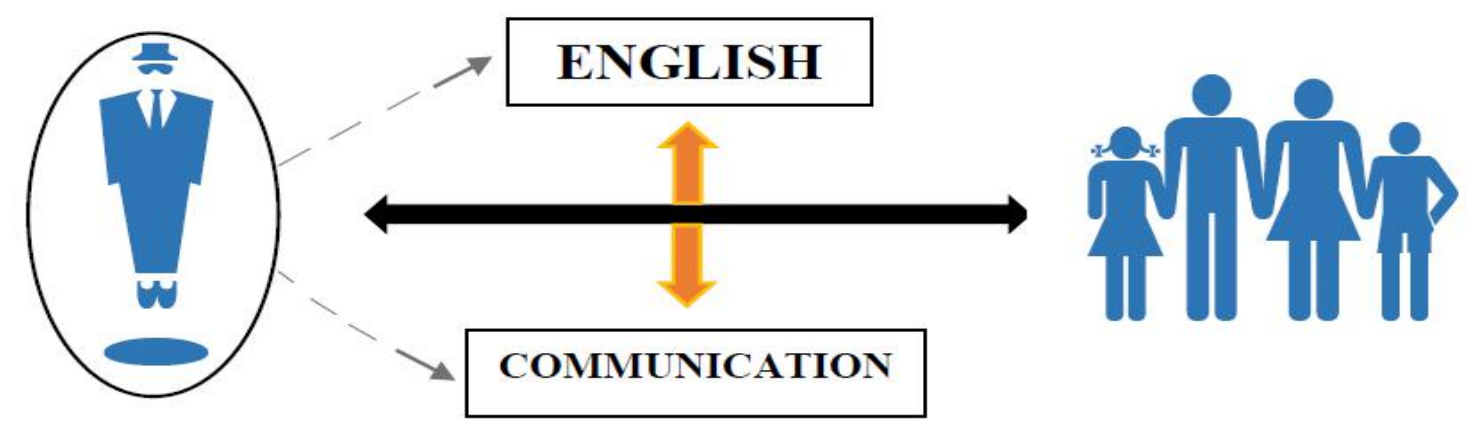

Figure 3

The relationship among CSO, English, communication, and international customers

As illustrated in Figure 3, the black line shows the interaction that happens between the CSOs and the international passengers, which is a two-way communications. However, this interaction can only be happened if both parties use their English language skills and communication skill, which is demonstrated by the vertical line. In order to provide the best service, it is mandatory for the CSOs to master English and effective communication skill, which illustrated by the dotted line. Therefore, if every aspect is present at the moment of interaction between the CSOs and the customers, it will create the best situation to provide an excellent service based on the company's standards.

\section{Customer Service Officers in Adisutjipto International Airport}

\section{The Requirement to Become a CSO in Adisutjipto International Airport}

To become a CSO in Adisutjipto International Airport, a candidate should meet the requirements from AP 1 JOG. The requirements were open for male and female, within the age of 18-28 years old (for male), and 18-25 years old (for female). The marital status should be single. The educational background of the candidate should, at least, high school graduate, or college graduate with either bachelor degree or diploma degree in English studies, Tourism, and Communication. As the requirements may state the job specification, the company must have to look more for the several qualities. According to the Head Section of Customer Service Section, the quality that the company needs are the candidates with a skill in oral and written English, having the ability to work under pressure, interpersonal skills, and having the ability to work in a team. Two out of four qualities matches Blanding's view on the qualification for a CSO candidate, which are having the ability to work under pressure and interpersonal skill.

\section{Work Routines as CSO in Adisutjipto International Airport}

Since the work system as CSO is using 'shift' system, one shift requires nine hours of working. The morning shift starts from $05.00 \mathrm{AM}-01.00 \mathrm{PM}$, whereas the night shift starts from 01.00 PM until the 
end of the flight schedule. The senior CSO have a day off in every three days of working. The responsibilities of the senior CSO include facility check at the beginning of every shift, authorising the temporary pass, answering common questions, and the works that require them to deliver goods or news to another terminal. The senior CSO also responsible for replying to complaints in social media, email, and the online complaint handling system in Adisujtipto International airport.

The responsibilities between the two terminals are slightly different. CSOs in terminal A had to stay in the cubicle around the arrival area and had to stay there until the end of the shift. The new system, however, expects the CSOs to have more contact with the passengers as the $\mathrm{CSO}$ will be moving around the waiting room areas and the lobby of the airport every one hour. In terminal B, every shift would have three persons. One person was from the information desk, and the other two were from Customer Service Section. The duties in terminal $\mathrm{B}$ include helping the information desk to answer the telephone and to board an airplane, changing the display, and making an announcement.

\section{The Performance of CSO in Adisutjipto International Airport}

\section{Skills in English Language Use}

Since the status of Adisutjipto International Airport is an international airport, the CSOs must be able to master several skill in English language use. On Prachanant's findings (2012), these skills are divided into four skills: listening, speaking, reading, and writing. During the internship program, researcher observed how the senior CSOs communicate with international passengers using English as a communication tool. Since nine out of ten personnels are college graduate in English studies, their English is at the intermediate level, and is eligible to work as a CSO in an international airport. Researcher found that speaking skills are a major requirement, and it has a significant place among other skills. This is because speaking skill is significant for the CSO to communicate with the passengers. Listening, on the other hand, came up at the second place, as it is important to understand their needs. However, contrasted to Prachanant's finding, researcher recognized that reading skill is rarely functioned in Adisutjipto International Airport. The explanation on this issue is because the CSOs also operate the social media and email, thus writing skill is more needed than reading skill.

\section{Communication and Functions of English Language Use}

There were several functions of English language use by the CSOs of Adisutjipto International Airport. The CSOs frequently used oral English to provide information to the international passengers. English also had become beneficial for CSOs to offer help to several passengers. English was also employed for answering question and solving problem as most of the international passengers usually asked moderate question, such as how get to Borobudur from the airport or how to get to Borobudur from Prambanan. However, the function of asking for cooperation, providing service and general conversation, 
as found in Prachanant's study (2012) were barely used.

Researcher further observed that the CSOs have met several standards of Macaulay and Cook's view on the effective communication. First, the CSOs always assisted the passengers in with warm, positive, and clear voice. Second, most of the CSOs were aware of their non-verbal communication, such as body language when assisting the passengers. Third, ithe CSOs were spontaneously asking more elaborate questions before providing answers to the passengers. These elements are only three out of five standards. I often found that most of the CSO provided a plain and basic information, such as when a passenger asked where Trans Jogja shelter is. Therefore, the performance on providing clear answer is far from the standard.

As for the attentive listening, the senior CSOs are still lacking in this area. Data analysis of this study found that they were lacking in showing their interest in the man's experience. It was also observed that non-verbal communication, such as body language, is vital for the CSO to communicate with several international passengers. This matches with Leland and Bailey's view. The CSOs only performed a major body language communication when the receiver of the information cannot speak in English or understand their explanation. This moment usually happened when the CSOs interacted with the Korean, Chinese or Japanese passengers.

\section{Problems in English Language Use}

The result of the study revealed that CSOs sometimes faced several issues in using English as communication tools in speaking area. Apart of encountering the situation where the passengers cannot speak in English, they often faced such problem of "lack of language equivalency" that they were not able to find the equal words from their mother tongue to English. This finding was similar with the result of Dumont and Lannon's study (1985: 494). Furthermore, most cases in speaking area is about using inappropriate words and several expressions in English. However, this study found several cases where the CSOs were unable to pronounce the right words more frequently than lacking in knowledge of grammar and structure. In communicating with passengers, grammar and structure are often forgotten since as long as the receiving end understands about the information CSO provides, which means that the message was received correctly.

In addition to this issue, the difficulties in listening area were also identified. First, the CSOs are having a hard time dealing with several accents from the non-native speakers. In most cases, the CSOs felt frustrated on communicating with several passenger from East Asia. Second, the issue of having a passenger asking or talking in quick pace made it hard for the CSO to catch the words. This finding was similar with Prachanant's study that the two elements have top places as common listening problem in English as a communication tool. However, the problem of writing skill for CSOs in Adisutjipto International Airport cannot be identified. The CSOs are mostly using their English orally, rather than in written way. The main reason is because the CSOs are communicating in the field with the 
passengers more frequently, and they did not have time to face paper works.

A routine evaluation might help the CSOs to have a better performance in using English as communication tool. Apparently, the evaluation for the performances of the CSOs is only conducted within the members of the Customer Service Section. The Customer Section Head conducts a meeting every once a month with the members of the CSOs. On this meeting, each person will evaluate the performances of other personnel. Therefore, every staff of the CSOs should attend the meeting. However, the company only gives evaluation once a year for the overall performances of the CSOs during their time of works.

\section{CONCLUSION}

Customer Service is one of various ways to win customers. It is a significant key for the company. A customer-focused firm will provide an excellent customer service in order for them to provide the best for the customers. In order to do that, it needs a section where it works and concentrates on customers. Therefore, a customer service section is established to help the company giving the best service based on the standard of that the company can facilitate.

Additionally, a customer service section needs proper human resources with communication skill. An effective communication requires far beyond only talking to the customers, such as language skill. For a verbal communication, it needs language skill to support the CSOs to know how to properly speak with the right use of language. Therefore, to achieve a successful customer service section, it needs the proper human resources with communication skill, and supported by having a language skill. It is significant to have a strong communication skill in verbal communication. Additionally, in order to have a successful and engaging communication with the international passengers, the CSOs have to master English as a global communication tool. The function in mastering English for CSO is not only to communicate, but also to open more opportunities for the company to grow internationally. Therefore, the two elements are essential for the CSOs to master.

The connection between the CSOs, the international passengers and communicative English is inseparable. The communication between the CSOs and the international passengers is a two-way communication. A successful two-way communication between the two parties cannot be separated from their communication skills and English language ability. The two elements is the core of this communication to happen. This is reasonable because people need communication skill to communicate their needs, and English has risen as a global communication tool to facilitate people from different languages to communicate between each other. Furthermore, in order to provide service, the CSOs must have the skill of communication and English as the core of their ability to build a relationship with the international passengers.

As part of important entity of international airport, the CSOs' ability in communication and English is vital since they are the first line attack and defence in communicating with passengers. Therefore, examining their performance in the practice 
of communicative English can be useful to identify their skills in this area in recognition of the airport's international status. Moreover, it can also be the measurement to evaluate the performance of English ability of the CSO in Adisutjipto International Airport to provide a better service.

\section{REFERENCES}

Adisutjipto International Airport

Yogyakarta. adisutjipto-airport.co.id.

Blanding, W. (1991). Customer Service:

The Complete Guide. Amacom.

Brink, A. \& Berndt, A. (2004). Customer Relationship Management \& Customer Service. Lansdowne.

Crystal, D. (1997). English as Global Language. Cambridge University Press.

Dumont, R.A. \& Lannon, J.M. (1985).

Business Communications. Little,

Brown \& Company.

Leland, K. \& Bailey, K. (2011). Customer Service for Dummies ( $3^{\text {rd }} E d$ ). Wiley Publishing Inc.

Macaulay, S. \& Cook, S. (1993). How to Improve Your Customer Service. Kogan Page Limited.

Newby, T. \& McManus, S. (1991). The Customer Service Pocketbook. Management Pocketbook Ltd.
Prachanant, N. (2012). Need Analysis on English Language Use in Tourism Industry. Procedia: Social and Behavioral Sciences. 120-123.

John Hopkins Health System Guidebook. (2010). Service Excellence and Standard Behavior: Employee Reference Guide.

Seidlhofer, B. (2005). English as lingua franca. ELT Journal, 59.

Shankman, P. (2010). Customer Service: New Rule for Social Media World. Pearson Education, Inc.

Sharifian, F. (2009). English as International Language: Perspectives and Pedagogical Issues. Library of Congress Cataloging.

Sutopo \& Suryanto, A. (2001). Pelayanan Prima: Bahan Ajar Diklat Prajabatan Golongan III. Lembaga Administrasi Negara.

World Tourism Organization. International Tourism Arrival Up 4\% Reach a Record 1.2 Billion in 2015. http://media.unwto.org/pressrelease/2016-01-18/internationaltourist-arrivals-4

Yoeti, O.A. (1995). Hotel Customer Service. PT. Perja. 